\title{
EDUKASI PEGELOLAAN BISNIS WISATA KULINER DI KOTA KENDARI
}

\section{EDUCATION OF CULINARY BUSINESS MANAGEMENT IN KENDARI CITY}

\author{
Tuti Dharmawati, Sulvariany Tamburaka \\ Fakultas Ekonomi dan Bisnis, Universitas Halu Oleo, Kendari, Sulawesi Tenggara \\ Jalan H.E.A. Mokodompit, Kota Kendari, Sulawesi Tenggara, 93132 \\ Alamat korespondensi: tuti_balaka@yahoo.co.id \\ (Tanggal Submission: 15 Januari 2020, Tanggal Accepted: 15 April 2020)
}

\begin{abstract}
ABSTRAK
Berbagai keunggulan usaha kuliner perlu lebih dikembangkan untuk meningkatkan pendapatan dan kesejahteraan pengusaha kuliner, dan masyarakat. Perkembangan jumlah pengusaha kuliner terus meningkat termasuk Kota Kendari, hal tersebut menunjukkan bahwa usaha tersebut semakin diminati oleh masyarakat karena mempunyai prospek yang cukup baik. Namun demikian, pengusaha kuliner tidak hanya mendapatkan keuntungan atau penghasilan dari usaha kuliner yang dihasilkan tetapi terdapat side business dari usaha tersebut. Pengusaha kuliner dan masyarkat dapat memaksimalkan potensi ini yang kadang-kadang terlupakan. Potensi side business dari usaha kuliner yang cukup potensial untuk menambah pendapatan. Permasalahan, Beberapa permasalahan yang terkait dengan permasalahan Side business dari usaha kuliner di Kota Kendari, yaitu: pemahaman dan pengetahuan pengusaha kuliner terkait side business wisata kuliner. Solusi, merubah pola piker pengusaha kuliner serta masyarakat tentang side business. Target Kegiatan, Capaian kegiatan yang dihasilkan melalui pelaksanaan pengabdian ini akan mampu meningkatkan pemahaman pengusaha kuliner tentang manfaat atau keuntungan mengelolah Side Business wisata kuliner. Adapun target yang ingin dicapai dalam kegiatan ini adalah: Peningkatan pemahaman pengusaha kuliner tentang manfaat atau keuntungan mengelolah Side Business wisata kuliner, dan Peningkatan pengetahuan (kapasitas) pemahaman pengusaha kuliner sehingga mampu mengelolah atau memanfaatkan Side Business wisata kuliner
\end{abstract}

Kata kunci : Side Business, Wisata Kuliner

\section{PENDAHULUAN}

\section{Analisis Situasi}

Menurut penelitian dari Dr. David McCelland, seorang psikolog dari Harvard University, dalam bukunya yang berjudul The Achieving Societymenunjukkan bahwa suatu negara dapat mencapai kemakmuran dan kesejahteraan apabila minimal $2 \%$ dari jumlah penduduknya menjadi pengusaha. Hal tersebut mengindikasikan bahwa, negara Indonesia membutuhkan paling tidak sekitar 5 juta dari total 230 juta penduduknya untuk menjadi pengusaha.

Data Kementerian Koperasi dan Usaha Kecil Menengah (UKM) menyebut, jumlah wirausaha saat ini sudah mencapai rasio $3,1 \%$ dari total populasi penduduk Indonesia. Angka ini sudah melampaui standar internasional, yakni sebesar $2 \%$. Itu artinya jumlah pengusaha di Tanah Air sudah mencapai sekitar 8,06 juta jiwa dari 260 juta penduduk. Namun rasio ini masih kalah Malaysia yang berada di level 5\%, Singapura 7 persen dari total 4 juta penduduknya. Amerika memiliki pengusaha lebih dari $12 \%$, Jepang dan China lebih dari $7 \%$.

Jiwa entrepreneurship atau jiwa pengusaha memang perlu ditumbuhkan dalam diri anak muda. Karena merekalah yang menjadi ujung tombak dalam memakmurkan negara. Apabila semakin banyak pemuda Indonesia yang memiliki 
jiwa pengusaha, maka akan semakin besar juga kesempatan untuk bekerja karena banyaknya lapangan kerja yang tersedia. Hal ini tentu saja beriringan dengan semakin banyak pula harapan kesejahteraan bagi penduduk Indonesia.

Poin-poin yang telah disebutkan di atas hanyalah sebagian kecil dari ide usaha sampingan yang berkembang dan populer beberapa tahun belakangan ini. Bagaimanapun juga, masih ada ratusan bahkan ribuan ide usaha sampingan lain yang masih belum terungkap dan menunggu seseorang untuk segera menjalankannya. Selalu berpikir kreatif akan mengantarkan Anda pada sebuah ide yang belum pernah ada sebelumnya sehingga peluang sukses pun semakin besar.

Makanan Merupakan Kebutuhan Pokok, ketika berbicara soal suatu produk yang memiliki manfaat cukup luas, maka bisa dipastikan memiliki pangsa pasar yang luas pula. Begitupun dengan bisnis kuliner, semua membutuhkan makanan. Sehingga target pasarnya pun begitu luas dan bisa untuk banyak kalangan (tergantung jenis kuliner yang dijalankan). Kita ambil contoh KFC (Kentucky Fried (hicken) atau Pizza Hut. Mereka telah berhasil memposisikan dirinya sebagai salah satu kuliner yang wajib dinikmati ketika seseorang jalan-jalan ke kota. Target pasarnya pun untuk semua kalangan. Anak-anak, remaja dan orang dewasa menikmatinya.

Usaha kuliner adalah salah satu yang sangat penting dan jelas prospekif karena kebutuhan makanan tidak bisa dihindari. Selain menguntungkan dan unik mengangkat makanan khas daerah kota Kendari serta dapat menjadi daya tarik tambahan bagi pengunjung usaha kuliner. Salah satu poin yang menjadi alasan bisnis kuliner salah satu peluang usaha terbaik adalah keuntungan. Keuntungan yang diperoleh rata-rata lebih dari $50 \%$ dari modal bahan. Keuntungan kotor dikurangi berbagai kebutuhan penunjang. Usaha terbaik adalah suatu usaha yang cepat kembali modal. Artinya, bisnis kuliner masuk dalam kriteria tersebut. Jika perputaran uang cepat, maka modal yang digunakan akan cepat kembali. Selanjutnya tinggal menikmati keuntungan. Bisnis kuliner salah satu ide usaha yang hanya membutuhkan modal kecil, namun dapat memperoleh keuntungan yang besar. Misalnya saja menjalankan usaha gorengan, hanya butuh pisang, tepung atau minyak goreng yang harganya cukup murah.

Kebiasaan yang tidak pernah hilang dari para wisatawan, baik lokal maupun mancanegara adalah berburu kuliner khas daerah. Bahkan, setiap daerah saat ini sepertinya berlomba-lomba untuk memamerkan ciri khas dari olahan makanan mereka. Setiap daerah mulai membangun suatu wilayah khusus diperuntukkan untuk wisata kuliner.

Selain dari hal tersebut, untuk mengukur prospek dari bisnis kuliner ini, Anda bisa memperhatikan kebiasaan para pengguna media sosial. Setiap ingin menyantap makanan, pasti menyempatkan berselfie ria dengan fokus utamanya adalah makanan mereka. Sehingga walaupun berpindah tempat atau dibuka cabang yang baru, pelanggan yang loyal akan menjadi marketing gratis bagi usaha kuliner tersebut. Jumlah pegawai disesuaikan pula dengan jumlah pelanggan yang semakin meningkat. Selain itu, maraknya bisnis online menjadikan hampir semua jenis bisnis harus menyesuaikan diri agar mampu bertahan. Salah satu perubahan trend yang terjadi pada bisnis kuliner adalah layanan antar.

Setiap orang pasti ingin memiliki kenangan dari tempat istimewa yang dikunjunginya. Biasanya berbentuk kaus atau suvenir serta makanan khas dari bahan-bahan lokal yang khas di daerah itu. Sehinga perlu membuat suvenir yang khas yang akan menambah kekuatan wisata kuliner. Selfi adalah kegiatan yang sekarang ini diminati semua orang. Tetapi tak semua orang bisa menghasilkan foto yang keren. Tidak semua orang pula tahu tempat mana saja yang menarik buat berfoto. Maka, memberikan jasa fotografi masih menjadi peluang usaha di tempat wisata kuliner yang bisa dikembangkan.

Permasalahan, Hasil survey awal telah dilakukan dan menyimpulkan beberapa permasalahan yang terkait dengan Side business dari usaha kuliner di Kota Kendari, yaitu:

1. Pemahaman/pengetahuan pengusaha kuliner tetang manfaat dan keuntungan Side Business dari usaha kuliner sangat kurang/minim.

2. Pengetahuan atau kemampuan pengusaha kuliner dalam mengelolah Side Business dari usaha bisnis kulineran relative sangat kurang/minim. 


\section{METODE KEGIATAN}

\section{Solusi Yang Ditawarkan}

Untuk memecahkan berbagai masalah yang dihadapi oleh para pengusaha kuliner di Kota Kendari, maka kegiatan pengabdian ini menawarkan beberapa kegiatan sebagai solusi, yaitu:

1. Perubahan pola pikir dan perilaku masyarakat harus didekati dengan memberikan informasi, pengetahuan dan pemahaman sehingga nantinya akan memunculkan cara pikir baru (new thingking) yang lebih produktif dan lebih efektif.

2. Untuk memberikan pengetahuan dan informasi, maka kegiatan yang akan dilakukan berupa:
a. Penyuluhan tentang manfaat dan keuntungan Side Business usaha kuliner.
b. Penyuluhan tentang cara mengelolah atau memanfaatkan Side Business Usaha kuliner

\section{Target Kegiatan}

Capaian kegiatan yang dihasilkan melalui pelaksanaan pengabdian ini akan mampu meningkatkan pemahaman pengusaha tentang manfaat atau keuntungan mengelolah Side Business kuliner. Adapun target yang ingin dicapai dalam kegiatan ini adalah :

1. Peningkatan pemahaman pengusaha tentang manfaat atau keuntungan mengelolah Side Business kuliner.

2. Peningkatan pengetahuan (kapasitas) pemahaman pengusaha sehingga mampu mengelolah atau memanfaatkan Side Business kuliner.

\section{Metode pelaksanaan}

Kegiatan pegabdian di Kota Kendari akan dilaksanakan dengan dua tahap yaitu tahap persiapan dan tahap pelaksanaan.

1. Persiapan

Tahap persiapan yaitu mempersiapkan kebutuhan kegiatan Penyuluhan Pemanfaatan Side Business usaha kuliner di Kota Kendari
a. Pengurusan surat ijin kepada pengusaha kuliner di Kota Kendari
b. Mempersiapkan kelengkapan untuk pelaksanaan penyuluhan
c. Membuat dan mengirimkan surat usaha kuliner yang menjadi target sasaran penyuluhan.

2. Pelaksanaan Kegiatan

Pelaksanaan kegiatan penyuluhan pemanfaatan Side Business usaha kuliner di Kota Kendari melingkupi kegiatan sebagai berikut :

a. Kegiatan ini menjelaskan manfaat Side Business usaha kuliner .

b. Kegiatan ini menjelaskan bagaimana mengelolaah atau memanfaatkan Side Business.

c. Kegiatan menjelaskan produk-produk yang mungkin menjadi Side Business .

\section{Sasaran Kegiatan}

Sasaran penyuluhan ini pengusaha bisnis wisata kuliner di Kota Kendari.

4. Evaluasi

Evaluasi pelaksanaan kegiatan sangat dibutuhkan dalam rangka mencapai tujuan kegiatan. Rancangan evaluasi pada kegiatan ini dilakukan oleh tim dengan evaluasi yang komprehensif yakni melakukan evaluasi sebelum dan sesudah kegiatan pengabdian dilaksanakan. Evaluasi meliputi indikator:
a. Pemahaman peserta terhadap materi yang diberikan.
b. Antusianisme dalam melakukan kegiatan.
c. Kejelasan materi yang diberikan.
d. Kemudahan dalam menerima materi.
e. Cara pemateri menyampaikan materi.

\section{Gambaran Iptek}

Program Pengembangan Kewirausahaan (PPK) ini dengan fokus :

1. peningkatan kualitas lingkungan melalui penataan kawasan wisata kuliner dan

2. kesejahteraan melalui pemberdayaan masyarakat yang berwawasan kekhasan lokal yang mendukung terciptanya Kota Kendari sebagai Kota Hijau, Kota Wisata dan Ramah Lingkungan.

Adanya keinginan masyarakat untuk didampingi dalam proses penataan lingkungan wisata kuliner. Adanya kesediaan masyarakat untuk dibina dalam peningkatan pendapatan, 
pengembangan wirausaha, pembinaan dan pengembangan industri rumah makan yang berorientasi pada peningkatan pendapatan masyarakat dan pendapatan asli daerah. Oleh karena itu masyarakat perlu pembinaan dalam berbagai aspek yang berhubungan dengan pertumbuhan ekonomi daerah dan perbaikan lingkungan.

\section{HASIL DAN PEMBAHASAN}

Penyuluhan/edukasi dilakukan setelah tim pelaksana melakukan identifikasi tentang berbagai permasalahan yang dihadapi oleh pengusaha kuliner di Kota Kendari, sehingga disimpulkan bahwa perlunya melakukan penyuluhan terkait dengan tema yang diusung dalam pengabdian ini yaitu Edukasi Peningkatan Pendapatan Side Business Pengusaha Kuliner di Kota Kendari. Beberapa permasalahan yang dihadapi oleh pengusaha kuliner dan masyarakat di Kota Kendari, yaitu:

1. Pemahaman/pengetahuan Pengusaha Kuliner tetang manfaat dan keuntungan Side

Business dari usaha bisnis kulineran relative sangat kurang/minim.

2. Pengetahuan atau kemampuan Pengusaha Kuliner dalam mengelollah Side Business dari usaha bisnis kulineran relative sangat kurang/minim.

Permasalahan yang dihadapi Pengusaha Kuliner dan masyarakat di Kota Kendari perlu mendapat solusi khususnya diperlukan usaha atau kegiatan untuk meningkatkan pendapatan agar masyarakat memiliki pemahaman dan keterampilan usaha untuk meningkatkan pendapatan masyarakat.

\section{Persiapan Teknis}

Untuk suksesnya kegiatan penyuluhan tersebut dilakukan beberapa persiapan. Persiapan yang dilakukan oleh tim pelaksana kegiatan penelitian, yaitu:

1. Berkoordinasi dengan pengusaha kuliner dan masyarakat Kota Kendari untuk pelaksanaan kegiatan penyuluhan tersebut, khususnya terkait dengan tempat, waktu dan fasilitas pendukung pelaksanaan kegiatan termasuk undangan.
2. Berkoordinasi dengan pengusaha kuliner dan masyarakat terkait dengan konsumsi dan kelengkapan lain dalam kegiatan.

\section{Partisipasi Masyarakat}

Pencarian waktu pelaksanaan yang tepat, hal tersebut dilakukan agar bisnis kuliner dan masyarakat Kota Kendari yang mayoritas mempunyai pekerjaan dapat hadir tanpa mengorbankan banyak waktu kerja masyarakat. Pemahaman Pengusaha Kuliner dan masyarakat terkait dengan pentingnya kegiatan tersebut belum sama, sehingga dibutuhkan penjelasan yang lebih intensif.

Antusiasme masyarakat dalam menghadiri penyuluhan tersebut relatif cukup baik, hal ini dapat dilihat dari jumlah undangan yang disebar dengan jumlah masyarakat yang hadir. Jumlah undangan yang disebar sebanyak 30 undangan dan masyarakat yang hadir sebanyak 30 orang, sehingga dapat disimpulkan bahwa tingkat kehadiran masyarakat dalam edukasi tersebut mencapai 100 persen.

Disamping tingkat kehadiran yang cukup tinggi partisipasi Pengusaha Kuliner dan masyarakat juga dapat dilihat dari keaktifan peserta penyuluhan dalam memberikan pendapat, komentar dan pertanyaan terhadap materi yang disampaikan. Beberapa peserta bertanya lebih dari satu kali, hal tersebut dikarenakan peserta ingin mengetahui lebih banyak terkait dengan isi materi yang disampaikan, bahkan meminta kepada moderator untuk membuka beberapa sesi pertanyaan sehingga pada kegiatan tersebut yang direncanakan dibuka dua sesi tanya jawab menjadi empat sesi.

\section{Kegunaan/Manfaat Kegiatan}

Beberapa manfaat yang didapatkan dalam kegiatan penyuluhan ini adalah adanya pemahaman baru kepada masyarakat terkait dengan potensi bisnis kuliner yang dimiliki oleh masyarakat Kota Kendari yang dapat meningkatkan beberapa pendapatan mereka. Potensi Side Business pengusaha kuliner Kota Kendari cukup potensial untuk dikelolah agar meningkatkan pendapatan Pengusaha Kuliner. Pengusaha Kuliner dapat mengelolah berbagai produk sampingan selain produk inti kuliner, seperti; handcraft, jasa foto, penjualan kue khas daerah, dan lain-lain. 


\section{Dampak Jangka Panjang}

Edukasi tersebut diharapkan memberikan dampak yang signifikan pada bisnis kuliner serta masyarakat di Kota Kendari pada masa yang akan datang. Pengelolaan Side Business pengusaha kuliner Kota Kendari akan memberikan dampak pada pendapatan bisnis kuliner ayam disamping itu dapat meningkatkan lapangan pekerjaan bagi masyarakat di Kota Kendari dalam mengelolah Side Business pengusaha kuliner.

\section{Tindak Lanjut}

Agar kegiatan yang telah dilakukan benarbenar memberikan dampak yang signifikan dan bekelanjutan bagi Pengusaha Kuliner dan masyarakat Kota Kendari, maka Tim Pelaksana merasa perlu untuk menjadikan pengusaha kuliner Kota Kendari sebagai Pengusaha Kuliner binaan Fakultas Ekonomi dan Bisnis Universitas Halu Oleo.

Sebagai pengusaha kuliner binaan maka hubungan emosional dan kerjasama akan terus berlangsung. Secara berkala akan ada kegiatan yang berkelanjutan dan situasional baik yang terkait dengan tema penyuluhan in maupun yang tidak, namun merupakan permasalahan yang dihadapi pengusaha kuliner dan masyarakat Kota Kendari.

\section{KESIMPULAN DAN SARAN}

\section{Kesimpulan}

1. Pengusaha kuliner Kota Kendari memiliki potensi peningkatan pendapatan dengan melakukan pengelolaan Side Business usaha pengusaha kuliner.

2. Pengelolaan Side Business usaha pengusaha kuliner Kota Kendari dapat berupa pemanfaatan suasana tempat bisnis kuliner tersebut. Selain itu, pengelolaan jenis handcraft dan promosi makanan/kue khas daerah merupakan potensi yang sangat baik.

Saran

Agar memberikan dampak yang signifikan bagi masyarakat, maka pelaksanaan pengabdian kedepan sebaiknya ditempatkan lagi pada pengusaha kuliner Kota Kendari atau berkesinambungan baik terkait dengan tema pengabdian ini maupun mengusung tema baru.

\section{DAFTAR PUSTAKA}

Undang Undang Republik Indonesia Nomor 20 Tahun 2008 Tentang Usaha Mikro Kecil dan Menengah.

Peraturan Pemerintah Nomor 41 Tahun 2011 tentang Pengembangan Kewirausahaan dan kepeloporan pemuda, serta penyediaan prasarana dan sarana

Kementerian Perencanaan Pembangunan Nasional tahun 2014 tentang norma standar prosedur dan kriteria pengembangan kewirausahaan

Muh Yunus. 2008. Islam dan Kewirausahaan Inovatif, Malang: UIN Malang Press. 